\title{
Effect of Sanitation on Health of Prisoner Physical in Class IIA Bekasi
}

\author{
Muhammad Fahrurroji ${ }^{1^{*}}$ \\ ${ }^{1}$ Manajemen ilmu pemasyarakatan, Politeknik Ilmu Pemasyarakatan \\ *Corresponding author, e-mail: fahrurrojidompu24@gmail.com
}

Received 2020-03-28;

Revised 2020-04-26;

Accepted 2020-05-02;

Published Online 2020-05-30

\section{Conflict of Interest \\ Disclosures:}

The authors declare that they

have no significant competing

financial, professional or personal interests that might have influenced the performance or presentation of the work described in this manuscript.

\begin{abstract}
Health for prisoners is very important and good sanitation is a factor in creating health itself. The purpose of this study was to determine the condition of the sanitation factors that influence the health conditions of inmates in Bekasi Class IIA Penitentiary. This type of research is quantitative descriptive with the cross-sectional approach by comparing independent variables and dependent variables identified only once and at the same time. From the results of the dissemination and evaluation by the prisoners. The results showed that the condition of residential cells in Lapas Class IIA Bekasi was good. This can be seen from the average obtained on the condition of residential cell forging conditions that show a scale above 4 , which means the respondents agree that the condition of the residential cell is good. Based on research conducted by researchers in Bekasi Class IIA Lapas, it shows that the sanitation condition of Lapas affects the health conditions of prisoners. Following the concept of the epidemiological triangle of causes and processes of disease occurrence.
\end{abstract}

Keywords: sanitation, health, effect

\section{Introduction}

Penitentiary is one of the Technical Implementation Unit in the Directorate General of Corrections Kemenkumham RI that implements the coaching duties of prisoners it is stated in Law No. 12 of 1995 which states that the prison is the place to carry out training for prisoners and the students correctional (Law No. 12 of 1995 ). The coaching program is a means of educating inmates so that it can be accepted again in the community, but in its implementation, there are still many problems that interfere with the coaching program in prison so that the coaching program in prison is not running optimally(Putra et al., 
2019). One of the problems is the number of prisoners or prisoners who are overcrowded, which has several subsequent impacts, among others causing health facilities received by prisoners to be limited, poor air quality, limited clean water, and also a sanitation system that is bad because the number of prisoners is beyond capacity. Overcapacity level in prisons can be seen through the following table:

Overcapacity Levels of Prisons in Bekasi and surrounding areas:

Table 1 Level of prison overcapacity in Bandung

\begin{tabular}{lccc}
\hline Satker Name & Capacity & Content & Overcapacity Level \\
Lapas Class IIA Bekasi & 470 & 1461 & $211 \%$ \\
\hline Prison Class IIA Cikarang & 1699 & 1130 & $50 \%$ \\
Cibinong Class IIA Prison & 1464 & 930 & $57 \%$ \\
Cipinang Class I Prison & 880 & 4143 & $371 \%$ \\
\hline Prison Class II A Salemba & 572 & 1829 & $220 \%$ \\
\hline
\end{tabular}

Sumber (Correctional Database System, 2020)

This continued impact certainly causes a complex problem where the quality of services provided to WBP is very poor and far below the standards specified in the SMR ( Standard Minimum Rules of Treatment for Prisoners ) This poor condition will have an impact on sanitation in prisons. Poor basic facilities received by inmates cause poor prisoners' health levels and are marked by the number of prisoners who suffer from various diseases and affect the health conditions of prisoners who are in prison (Utami, 2017).

According to Richard Sihite sanitation is a health preventive effort that focuses on efforts to maintain the environmental health conditions of humans. The level of health is determined by several factors namely behavior, environment, order and health services (Efendi \& Makhfudli, 2010). From this explanation, it can be seen that the environment and behavior influence the prisoner's health level. This is our reference in conducting this research, namely the writer is trying to find the relationship and influence of environmental sanitation related to physical health conditions and community behavior towards the health level of Prisoners(Bukhori, 2012). From this background, the authors take the formulation of the problem in the form of how the relationship of environmental sanitation to prisoners' health in Class IIA Lapas Bekasi.

\section{Method}

This research was conducted to find out what are the factors that can affect the health of the inmates in Class II A Penitentiary in Bekasi. Type of research is a descriptive quantitative study with a cross-sectional approach. The study was cross-sectional is the kind of research that aims to determine the relationship between variables where the independent variables and the dependent variable is identified only once and at the same time. The population in this study were all Prisoners in Lapas Class IIA Bekasi. This study took 30 people from all prisoners to be sampled as research subjects. A sampling of prisoners is done using a simple random sampling technique, where respondents are chosen by researchers randomly. Primary data collection was directly obtained from research subjects using a questionnaire that is giving several questions or written statements to respondents to be answered.

Data collection used by researchers is a questionnaire or questionnaire that is tailored to the purpose of the research made. The data collection questionnaire instrument consisted of 2 parts, namely the first part included demographic data on sample identities including type, age, and latest education. The second part of the questionnaire covers the conditions of the residential cell and cell facilities in the prison, hygiene behavior and the level of knowledge about hygiene, health services and health complaints experienced by prisoners. In this study, researchers used a Likert scale in the form of a checklist so that researchers hope to get a firm answer regarding the data obtained. The researcher's questions consist of positive and negative 
questions. Answers from respondents were made with a vulnerable score of the highest score of 5 to the lowest score of 1 . For each positive question, namely answers Strongly Agree $=5$, Agree $=4$, Neutral $=3$, Disagree $=2$, Strongly Disagree $=1$. While the categories for each negative question, namely Strongly Disagree $=5$, Disagree $=4$, Neutral $=3$, Agree $=2$, Strongly Agree $=1$.

\section{Results and Discussion}

\section{A. Environmental Sanitation}

Environmental sanitation is closely related to the advice of infrastructure that wins waste disposal. Environmental sanitation also discusses the maintenance of environmental hygiene conditions through waste and waste management. Referring to the above understanding, several things fall within the scope of environmental sanitation, namely (Notoatmojo, 2003) : (1) Provision of clean water/water supply: this includes monitoring the quality, quantity, and utilization of water. (2) Waste processing ( refuse disposal ): this includes the method of garbage disposal, garbage disposal equipment and how to use it. (3) Food and beverage processing: this includes the procurement, storage, processing, and management of food. (4) Monitoring/control insects and rodents (insect and rodent control ): This covers how to control and rodent attack. (5) Occupational health and safety: carry out OHS activities which include workspace (eg kitchen), work, work methods, and labor.

The maintenance of good environmental sanitation aims to ensure the maintenance of environmental hygiene conditions so that a condition that is following health standards is realized. Also, sanitation aims to restore, improve, and maintain human health. With the realization of environmental conditions that meet health requirements, the production process will be better and produce products that are healthy and safe for humans. Examples of good environmental sanitation include : (1) Creating and managing waterways. (2) Create and regulate household waste disposal channels. (3) Disposing of trash in the space provided. (4) Provision of clean and well-maintained public toilet facilities. (5) Management of waste/garbage properly, regularly, and continuously. For example by recycling trash.

Good environmental sanitation provides many benefits for the environment. As for some of the benefits of good environmental sanitation for human life. The creation of environmental conditions that are cleaner, healthier, and more comfortable for humans themselves and can also prevent infectious diseases. Besides, the creation of good sanitation will avoid environmental pollution and have an impact on the reduction in the percentage of people who are sick in an area.

In a study conducted at the hammer city class II A Penitentiary it was found that the habit of cleaning the environment carried out by inmates also had an effect on the quality of good sanitation on the environment of the correctional institution (Ningsih et al., 2019). In another study stated that the condition of water and air are also influenced by the condition of buildings and facilities and infrastructure that support the availability of clean water and clean air conducted by research in cilacap class II B prisons (Rahayu \& Subagiyo, 2018)

\section{B. Health}

Health is a concept that is often used, but the meaning is difficult to explain. However, most scientific sources say that any definition of health must contain at least a biomedical, personal, and sociocultural component (Notoatmojo, 2003). In Health Law No.23 of 1992, Health is defined more complexly as the well-being of the body, soul and social that enables everyone to live productively socially and economically. Not only is it free from physical, mental and social disturbances, but health is seen as a tool or a means for living productively.

\section{Theory of Epidemiology of the Causes of Disease}

The epidemiological triangle is a basic concept that provides an overview of the relationship between the three factors. this relationship plays a role in the process of disease and other health problems. The epidemiology triangle in fig. 1 describes the interaction between Host (Host), Agent (Cause) and Environment (Environment). Changes in one factor or component and will change the overall balance. 
The relationship between these three components is illustrated by the level in the scale, which is the environment as the foundation.
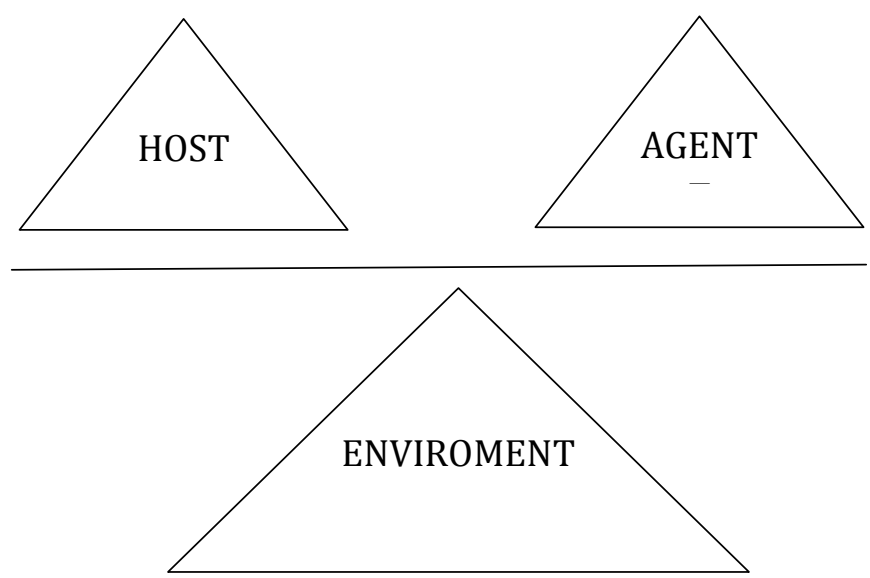

Fig. 1 Epidemiology triangle

The process and causes of disease occurrence in epidemiology that develops from the chain of cause and effect into a disease occurrence process that occurs in the process of interaction between humans and their various properties with causes (agents) and with the environment (environment).

In the case of poor levels of sanitation that affect prisoners' health conditions, the disease can arise due to the imbalance of the host, agent, and environment.

Host (Host) is a human condition that is a risk factor for the cause of a disease. Host/host This factor is caused by intrinsic factors. Host factors that arise in illnesses suffered by prisoners are (1) Health status, poor nutritional conditions due to nutrient intake that is not fulfilled maximally, making it easy for prisoners to suffer from the disease. (2) State of immunity and immune response. Poor environmental conditions coupled with poor nutritional intake causes many prisoners to have low immunity and disease.

No disease can arise due to a single factor. In general, the emergence of the disease is caused by various elements that simultaneously encourage the occurrence of the disease, but the elements causing the disease are divided into two main parts, namely: Primary Causal Causes, and Secondary Causal Causes.

The primary causal cause of disease occurrence in prisoners is the low level of environmental sanitation related to environmental cleanliness, airflow, lighting and waste disposal. Whereas the secondary causal cause is more on the knowledge of prisoners regarding the knowledge of healthy living habits which is very minimal, for example, awareness for bathing on time, awareness about the use of soap is lacking.

In environmental sanitation, environmental elements play an important role in determining individual characteristics as host factors and play a role in the process of spreading disease. As we know that the prison environment is known for its Overcrowded situation which causes overcrowded prison conditions which results in a bad physical environment. This is characterized by poor lighting conditions, poor air quality in prison cells due to overcrowded occupants, poor waste disposal quality due to the number of latrines that is not proportional to the number of occupants.

Of all the elements above, where the interaction between one another will determine the process and direction of the disease occurrence process, both in individuals and in society. Thus a disease occurs not only caused by the causative elements alone, but the main thing is how the chain of causes and the causal relationship that is influenced by various factors and other elements.

Based on the theoretical basis that has been explained, the framework of this research concept is described at fig. 2 as follows: 


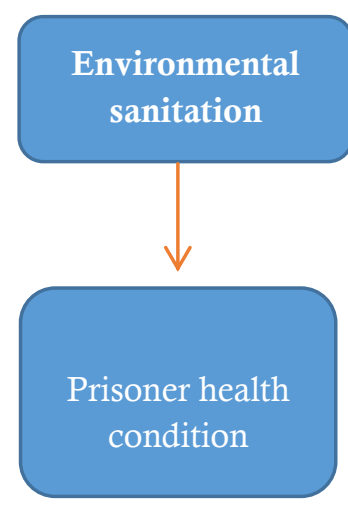

Fig. 2 The framework of this research concept

\section{Hypothesis}

$\mathrm{H}_{0}$ : Environmental Sanitation Influences Public Health Conditions

$\mathrm{H}_{1}$ : Environmental sanitation does not influence public health conditions

In this research. The validity testing of questionnaire items was carried out using the SPSS program. A variable indicator is said to be valid if the correlation coefficient between item scores and the total score obtained is greater or equal to the coefficients in the table $\mathrm{r}$ values ( $\mathrm{r}$ table) at $\mathrm{a}=5 \%$ then the item is declared valid, and vice versa the item is declared null if rxy is smaller than $r$ table. The value of $r$ table in this study is based on the number of trial subjects as many as 30 Prisoners in Class IIA Lapas Bekasi which is 0.361 (with sig. $5 \%$ ) (Nurhasanah, 2017)

\section{Univariate Analysis}

\section{Free Variable:}

\section{Factors of Shelter Cell Conditions in Prison}

Table 2 Average Results of Factors of Shelter Cell Conditions in Prisons

\begin{tabular}{c|c|c|c|c}
\hline $\begin{array}{c}\text { The lighting } \\
\text { conditions inside } \\
\text { the residential block } \\
\text { are good }\end{array}$ & $\begin{array}{c}\text { The condition of the } \\
\text { air ventilation and } \\
\text { the condition of air } \\
\text { circulation in the } \\
\text { housing block is good }\end{array}$ & $\begin{array}{c}\text { The availability } \\
\text { of clean water in } \\
\text { the residential } \\
\text { blocks is } \\
\text { sufficient }\end{array}$ & $\begin{array}{c}\text { Availability of a } \\
\text { good place for } \\
\text { bathing, washing, } \\
\text { and toileting in the } \\
\text { residential block }\end{array}$ & $\begin{array}{c}\text { There is good } \\
\text { sewage in the } \\
\text { prison. }\end{array}$ \\
4.40 & 4.17 & 4.37 & 4.40 & 4.40 \\
\hline
\end{tabular}

From table 4.5 it can be seen that the results show that the condition of residential cells in Lapas Class IIA Bekasi is good. This can be seen from the average obtained on the condition of the occupancy cell forging condition which shows a scale above 4 , which means the respondents agree that the condition of the residential cell is good which includes, (a) The lighting conditions in the residential block are very good. (b) The state of the air ventilation and the condition of air circulation in the housing block is good. (b) The availability of clean water in the residential blocks is sufficient. (c) The availability of a good place for bathing, washing, and toileting in the residential block. (d) There is good sewage in the prison. 


\section{Behavior Factors of Cleanliness Prisoners}

Table 3 Average Outcomes of Prisoner Behavior Factors

\begin{tabular}{c|c|c|c|c|c}
\hline $\begin{array}{c}\text { I shower at } \\
\text { least twice a } \\
\text { day }\end{array}$ & $\begin{array}{c}\text { I take a shower } \\
\text { using shower } \\
\text { soap }\end{array}$ & $\begin{array}{c}\text { I realized the } \\
\text { importance of } \\
\text { washing hands }\end{array}$ & $\begin{array}{c}\text { I always } \\
\text { change clothes } \\
\text { when it's dirty }\end{array}$ & $\begin{array}{c}\text { I always wash } \\
\text { clothes }\end{array}$ & $\begin{array}{c}\text { I often clean } \\
\text { the block } \\
\text { environment }\end{array}$ \\
4.73 & 4.73 & 4.73 & 4.80 & 4.83 & 4.67 \\
\hline
\end{tabular}

From table 8 it can be seen that the results show that the behavior of prisoners' hygiene in Bekasi Class IIA Prison is good. This can be seen from the average obtained on the behavior factors of prisoners' cleanliness which shows a scale above 4, which means the respondents agree and have been aware of the importance of clean living. The hygiene behavior factors in question are (a) Awareness of bathing at least twice a day. (b) Awareness of bathing using soap. (c) Awareness of washing hands. (d) Awareness of changing clothes. (e) Awareness of washing clothes. (f) Awareness of cleaning the block's environment(Azizah \& Subagiyo, 2018).

\section{Health Service Availability Factors}

Table 4 Average Results Of Availability Factors Health Services

$\begin{array}{ccc}\text { Clinical facilities in } & \text { The availability of } \\ \text { Lapas are adequate } & \begin{array}{c}\text { The number of health } \\ \text { Lapas Clinic is } \\ \text { adequate }\end{array} & \begin{array}{c}\text { Access to get permission to } \\ \text { workers in Lapas clinics } \\ \text { seek treatment at Lapas } \\ \text { Clinic is easy }\end{array}\end{array}$

\begin{tabular}{llll}
4.40 & 4.30 & 4.33 & 4.40 \\
\hline
\end{tabular}

From table 4.18 it can be seen that the average results indicate that the condition of the availability of health services in Class IIA prison in Bekasi is good. This can be seen from the average obtained in the condition of the availability of health services which shows a scale above 4 , which means the respondents agree that the availability of health services in Lapas Class IIA Bekasi is good. Availability services health include (a) facilities adequate prison clinic. (b) Availability of adequate drugs. (c) amount of adequate health workers. (d) Easy access to medical treatment permits at the clinic.

\section{Dependent variable}

\section{Health Complaints Factors experienced by Prisoners}

Table 5 Average Outcomes of Health Complaints Factors Experienced by Prisoners

\begin{tabular}{ccc}
\hline $\begin{array}{c}\text { I Often Experience } \\
\text { Complaints Of Illness }\end{array}$ & $\begin{array}{c}\text { I Often Went To The Lapas } \\
\text { Clinic For Treatment }\end{array}$ & $\begin{array}{c}\text { I Have Been Infected With } \\
\text { An Infectious Disease }\end{array}$ \\
3.30 & 2.30 & 4.10 \\
\hline
\end{tabular}

From the above table, it can be seen that the average inmate stated he tends to be neutral (3.30) in experiencing complaints of disease. In terms of the intensity of treatment of prisoners in prison clinics, on average they answered disagree (2.30) if they often seek treatment at Lapas clinics indicating that prisoners were rarely affected by the disease. And from disease transmission factors, the average inmate agrees that they often contract infectious diseases $(4,10)$. 


\section{Path Analysis and Hypothesis Testing}

Table 6 Variables Entered / Removed ${ }^{\text {a }}$

\begin{tabular}{|c|c|c|c|}
\hline Model & Variables Entered & Removed Variables & Method \\
\hline 1 & $\begin{array}{l}\text { Environmental } \\
\text { Sanitation }^{\mathrm{b}}\end{array}$ & & Enter \\
\hline \multicolumn{4}{|c|}{ a. Dependent Variable: Prisoner's Health } \\
\hline \multicolumn{4}{|c|}{ b. All requested variables entered. } \\
\hline
\end{tabular}

Table 7 Model Summary

\begin{tabular}{ccccc}
\hline Model & $\mathrm{R}$ & $\mathrm{R}$ Square & $\begin{array}{c}\text { Adjusted R } \\
\text { Square }\end{array}$ & $\begin{array}{c}\text { Std. Error of } \\
\text { the Estimate }\end{array}$ \\
1 &, $837^{\mathrm{a}}$ & .700 &, 400 &, 69873 \\
\hline & a. Predictors: (Constant), Environmental Sanitation \\
\hline
\end{tabular}

In the summary model table, it is known that the correlation value or $\mathrm{r}$ between the variables $\mathrm{X} 1$ and $\mathrm{X} 2$ is 0.837 . The coefficient of determination (KD) or $\mathrm{r}^{2}$ is 0.700 or $70 \%$, meaning that the environmental sanitation variable (X1) explains the prisoner health variable (X2) by $70 \%$. Meanwhile, the remaining $30 \%$ is explained by other variables not explained in the model.

Table 8 ANOVA Results

\begin{tabular}{|c|c|c|c|c|c|c|}
\hline & Model & $\begin{array}{c}\text { Sum of } \\
\text { Squares }\end{array}$ & $\overline{D f}$ & Mean Square & $\mathrm{F}$ & Sig. \\
\hline \multirow[t]{3}{*}{1} & Regression & 1,138 & 1 & 1,138 & 2,332 & $369^{\mathrm{b}}$ \\
\hline & Residual & 488 & 1 & 488 & & \\
\hline & Total & 1,627 & 2 & & & \\
\hline & & $\begin{array}{l}\text { Depende } \\
\text { dictors: (C }\end{array}$ & able: & $\begin{array}{l}\text { oner's Health } \\
\text { Imental Sanita }\end{array}$ & & \\
\hline
\end{tabular}

ANOVA table is used to see the results of overall hypothesis testing about the presence or absence of a linear relationship of exogenous variables to endogenous variables. Simultaneously, the independent variables have a significant effect on health condition variables as indicated by the Sig. 0.369> Alpha 0.05 (5\%), which means accepting the null hypothesis $\mathrm{H}_{0}$ that there is a direct influence of environmental sanitation on the health condition of prisoners in prisons Class IIA Bekasi and reject the alternative hypothesis, meaning that there is influence between environmental sanitation and health conditions of prisoners. This means that the F statistical test is not significant

Table 9 Coefficients Results

\begin{tabular}{|c|c|c|c|c|c|c|}
\hline \multicolumn{2}{|r|}{ Model } & \multicolumn{2}{|c|}{ Unstandardized Coefficients } & \multirow{2}{*}{$\begin{array}{c}\text { Standardized } \\
\text { Coefficients } \\
\text { Beta }\end{array}$} & \multirow[t]{2}{*}{$\mathrm{T}$} & \multirow[t]{2}{*}{ Sig. } \\
\hline & & B & Std. Error & & & \\
\hline \multirow[t]{3}{*}{1} & (Constant) & $-22,794$ & 17,049 & & $-1,337$ & , 409 \\
\hline & $\begin{array}{c}\text { Environment } \\
\text { sanitation }\end{array}$ & 6,034 & 3,952 &, 837 & 1,527 &, 369 \\
\hline & & \multicolumn{5}{|c|}{ a. Dependent Variable: Prisoner's Health } \\
\hline
\end{tabular}

Based on the table above the significance value of the environmental sanitation variable is 0.369 . Environmental sanitation significance value $0.369>0.05$, which means accepting the null hypothesis $\mathrm{H}_{0}$ 
which means there is a direct influence of environmental sanitation and health conditions of inmates in prisons Class IIA Bekasi.

Based on path analysis and hypothesis testing found a relationship between environmental sanitation variables and prisoners' health conditions in Lapas Class IIA Bekasi. Environmental sanitation in Bekasi Class IIA Prison has a direct influence on prisoners' health conditions, this can be seen from the coefficient of determination (KD) or $\mathrm{r}^{2}$ of 0.700 or $70 \%$, meaning that the environment sanitation variable (X1) explains the prisoner's health variable (X2) of $70 \%$

\section{Conclusion}

Based on research conducted by researchers in Bekasi Class IIA Lapas, it shows that the sanitation condition of Lapas affects the health conditions of prisoners. Following the concept of the epidemiological triangle of causes and the process of disease occurrence, the cause and effect of disease events are caused by the process of interaction between humans (hosts) in this case Bekasi Class IIA prison inmates with causes in the form of environmental sanitation conditions (agents) and with the environment (environment) Lapas Class IIA Bekasi. In our research, sanitary conditions affect prisoners' health. The condition of good environmental sanitation affects the health conditions of prisoners who are also good which in the study of good prison sanitation conditions are characterized by three factors, namely: (a) Factors of the condition of decent residential cells. (b) Prisoner's hygiene behavior. (c) Availability of good health services. These three factors affect the prisoners' health conditions in the form of (a) The intensity of prisoners experiencing complaints of disease. (b) Intensitatas of prisoners seeking treatment at the Lapas Clinic. (c) Infectious disease infections experienced by inmates

\section{Acknowledgment}

This research is expected to be a reference in assessing the clean and proper condition of environmental sanitation in prisons to create good prisoner health conditions that have implications for the smooth development program. The researcher realizes that not all sanitary conditions in a prison environment in Indonesia are clean and proper so that the role of the Directorate General of Posts as a party must be increased as to have the authority to create proper sanitation conditions in every Indonesian Penitentiary UPT following the mandate of Law No. 12 of 1995 and basic standards stipulated in the SMR ( Standard Minimum Rules for Treatment of Prisoners).

\section{References}

Azizah, Q. N., \& Subagiyo, A. (2018). Deskriptif Hygiene Sanitasi Pengelolaan Makanan Di Lembaga Pemasyarakatan Kelas Iib Kabupaten Cilacap Tahun 2017. Buletin Keslingmas, 37(4), 475-481. https://doi.org/10.31983/keslingmas.v37i4.3799

Bukhori, B. (2012). Hubungan kebermaknaan hidup dan dukungan sosial keluarga dengan kesehatan mental narapidana (Studi kasus nara pidana Kota Semarang). Ad-Din, 4(1), 1-19.

Efendi, F., \& Makhfudli. (2010). Keperawatan Kesehatan Komunitas. Salemba Medika. https://doi.org/10.13140/RG.2.1.1178.5366.

Ningsih, A. S., Budiman, \& Alief, A. R. (2019). Analisis kondisi sanitasi dan personal hygiene narapidana di lembaga pemasyarakatan klas iia kota palu. Jurnal Kolaboratif Sains, 1, 196-203.

Notoatmojo. (2003). Pendidikan dan Perilaku Kesehatan. Rineka Cipta.

Nurhasanah, S. (2017). Praktikum Statistika 2 Untuk Ekonomi dan Bisnis. Salemba Empat.

Putra, A. S., Rai Yuliartini, N. P., \& Sudika Mangku, D. G. (2019). Sistem Pembinaan Terhadap Narapidana Narkotika di Lembaga Pemasyarakatan Kelas IIB Singaraja. 2(1). 
Rahayu, D. S. A., \& Subagiyo, A. (2018). Studi Sanitasi Lembaga Pemasyarakatan Kelas Iib Dikabupaten Cilacaptahun 2017. Buletin Keslingmas, 37(2), 204-211. https://doi.org/10.31983/keslingmas.v37i2.3866

Utami, P. N. (2017). Keadilan Bagi Narapidana di Lembaga Pemasyarakatan. Jurnal Penelitian Hukum De Jure, 17(3), 381. https://doi.org/10.30641/dejure.2017.v17.381-394

Article Information (Supplementary)

Conflict of Interest Disclosures:

The authors declare that they have no significant competing financial, professional or personal interests that might have influenced the performance or presentation of the work described in this manuscript.

Copyrights Holder: < Fahrurroji $><2020>$

First Publication Right: BISMA The Journal of Counseling

http://dx.doi.org/10.23887/bisma.v3i1

Open Access Article | CC-BY Creative Commons Attribution 4.0 International License.

Word Count: 3817 